\title{
AZJA POKUDNIOWO-WSCHODNIA
}

\section{Krzysztof Szumski}

\section{INDONEZJA - SZANSE I WYZWANIA}

Wśród wielkich państw Azji Indonezja jest chyba w Polsce najmniej znana. Dla wszystkich, którzy mieli jednak możliwość przynajmniej trochę ten kraj zwiedzić i zetknąc się z jego mieszkańcami, jest on ciekawy, nawet fascynujący, budzi podziw i sympatię, choć czasem i smutek połączony z rozczarowaniem. Jest potencjalnym wielkim mocarstwem w regionie, a może i na świecie, ale realizacja tych możliwości ciągle odsuwa się w czasie. Współczesna złożona sytuacja kraju stawia wysoki próg trudności przed wszystkimi, którzy próbują przedstawić dzisiejszą Indonezję możliwie obiektywnie i klarownie. Wyłącznie doświadczenia ponad czterech lat pracy w Indonezji na stanowisku ambasadora i autentyczne pozostawanie do dziś pod urokiem tego kraju skłoniły mnie do próby pokazania szans i wyzwań stojących przed współczesną Indonezją i jej mieszkańcami.

\section{Różnorodność, piękno i bogactwo - kraj wielkich nadziei i wyzwań}

Przedstawiając współczesną Indonezję, nie można nie poinformować - choćby w największym skrócie - o naprawdę wyjątkowym charakterze kraju. Szokuje jego rozmiar obejmujący powierzchnię lądową ok. 1,9 mln km kw., na którą składa się ponad 17,5 tys. wysp i wysepek (co do ich liczby można spotkać również inne dane), z których ok. 6 tys. jest zamieszkanych, o czym najczęściej decydują zasoby wody pitnej. Obszar morski kontrolowany przez Indonezję jest znacznie większy i wynosi ok. 7,9 mln km kw. Położenie kraju jest szczególne, bo rozdziela on dwa oceany - Indyjski i Spokojny - i stanowi równocześnie pomost pomiędzy kontynentami - Azją i Australią. Położenie to nadaje Indonezji duże znaczenie strategiczne, 
bo leży ona m.in. nad cieśniną Malakka, przez którą przechodzą gigantyczne ilości różnego rodzaju ładunków, w tym surowce energetyczne z Bliskiego Wschodu do Azji Wschodniej. W mniejszej skali dotyczy to także Cieśniny Sundajskiej pomiędzy Sumatrą a Jawą. Na uwagę zasługuje również, że Indonezja leży nad głębokimi cieśninami pomiędzy wyspami Bali i Lombok oraz cieśniną Makasar, pozwalającymi na przepływanie w zanurzeniu atomowych okrętów podwodnych, co ma znaczenie strategiczne dla wielkich mocarstw. By wyobrazić sobie obszar, jaki obejmują wyspy Indonezji, warto pamiętać, że odległość od jej północno-zachodniego krańca, tj. od wyspy Sabang, do krańca południowo-wschodniego, do miejscowości Merauke na Nowej Gwinei (prowincja Papua), odpowiada w przybliżeniu odległości z Londynu do Bagdadu lub z Nowego Jorku do San Francisco.

Wielkim skarbem Indonezji jest jej ludność, która w 2014 r. oceniana była na ok. 254,5 mln (dane Banku Światowego), co stawia kraj na czwartym miejscu na świecie pod względem liczby mieszkańców. Również według przewidywań demograficznych na rok 2050, dzięki przyrostowi naturalnemu Indonezja, z liczącą wówczas z ok. 274 mln ludnością, utrzyma swoje czwarte miejsce na świecie. Połowa społeczeństwa jest obecnie w wieku poniżej 30 lat. Ludność składa się z przedstawicieli różnych grup rasowych i etnicznych, których liczbę szacuje się od 150 do nawet 300. Największe grupy to Jawajczycy (40\%) i Sundajczycy (15\%), wymienić należy także inne ważniejsze, jak Madurowie, Minangkabau, Bugijczycy, Batakowie i Balijczycy. Władze indonezyjskie rozróżniają ok. 580 języków i dialektów lokalnych, urzędowym językiem jest indonezyjski - Bahasa Indonesia - stworzony po odzyskaniu niepodległości na bazie języka malajskiego, wzbogaconego elementami z innych języków. Język indonezyjski umacnia się dzięki stosowaniu go przez administrację państwową (urzędnicy muszą go opanować), wojsko i policję oraz media, ale są regiony, gdzie włada nim nie więcej niż 50\% ludności. W miastach żyje ponad 53\% mieszkańców. Na Jawie mieszka aż niemal 59\% całej ludności, ale na powierzchni tylko 6,9\% kraju, gdzie gęstość zaludnienia sięga 975 osób na kilometr kwadratowy. Ogólnie rozmieszczenie ludności jest bardzo nierównomierne, a na części indonezyjskiej Nowej Gwinei tylko nieznacznie przekracza sześć osób na kilometr kwadratowy.

Indonezja jest także różnorodna religijnie. Wprawdzie dominuje islam - ponad $86 \%$, w tym w olbrzymiej większości są to sunnici - ale inne religie, jak protestantyzm (6\%), katolicyzm (3\%), hinduizm (2\%) i buddyzm (1\%), także zajmują ważne miejsce. Formalnie uznawanych jest pięć wielkich religii światowych: islam, protestantyzm, katolicyzm, hinduizm i buddyzm. Konstytucja gwarantuje wolność praktyk religijnych, co znajduje wyraz w życiu codziennym.

Powodem do dumy dla Indonezyjczyków jest to, że ich kraj zajmuje trzecie miejsce pod względem ludności wśród krajów demokratycznych. Równocześnie 
Indonezja jest krajem o największej liczbie wyznawców islamu. Dewizą Indonezji jest jedność w różnorodności (Bhinneka Tunggal Ika), co dobrze oddaje charakter kraju i jego mieszkańców.

Wyspy tworzące Indonezję są w znacznej większości górzyste, a łańcuchy górskie wysp we wschodniej części kraju często w swoim przedłużeniu morskim poprzedzielane są głębinami sięgającymi nawet 7 tys. m, jak na Morzu Banda.

Rzeźba powierzchni jest niezwykle urozmaicona, na co wpływa jej niestabilność wynikająca z intensywnej aktywności sejsmicznej i wulkanicznej. Najwyższe szczyty górskie to najczęściej aktywne lub wygasłe wulkany, często znacznie przekraczają wysokość 3 tys. m, a na Nowej Gwinei sięgają 5 tys. m. Łączna liczba wulkanów przekracza 500, w tym ponad 120 jest czynnych.

Pod wpływem równikowego położenia i wyspiarskiego charakteru klimat jest przez cały rok ciepły i wilgotny, a wahania temperatury niewielkie, co powoduje m.in. występowanie gęstych lasów tropikalnych. Położenie wzdłuż równika sprawia, że warunki klimatyczne na większości wysp są podobne, a tylko na niektórych wyspach na wschodnich krańcach kraju przy sprzyjającym ukształtowaniu powierzchni pojawia się sawanna.

Indonezyjskie fauna i flora są niebywale bogate i urozmaicone. Na obszarze zaledwie nieco ponad 1\% powierzchni światowych lądów występuje zarówno wielka różnorodność ssaków - ok. 12\% wszystkich znanych na świecie gatunków, 16\% gadów i płazów oraz 17\% wszystkich gatunków ptaków. Jeżeli chodzi o gatunki roślin, to występuje ich $10 \%{ }^{1}$.

Niezwykle ciekawe jest zróżnicowanie przyrodnicze Indonezji. Dzieli się ona na większą część zachodnią z fauną i florą podobną do Półwyspu Malajskiego i część wschodnią, oddzieloną cieśninami morskimi między wyspami Bali i Lombok oraz cieśniną Makasar między Kalimantan (Borneo) i Sulawesi (Celebes), obejmującą Sulawesi oraz archipelagi Małych Wysp Sundajskich i Moluków. Oddzielną strefę tworzy indonezyjska część Nowej Gwinei należąca do szelfu australijskiego. Dzięki obserwacjom brytyjskiego zoologa i podróżnika z XIX w. Alfreda Russela Wallace'a wyodrębniono strefę pozostającą poza szelfem kontynentalnym azjatyckim, oddzieloną tzw. linią Wallace'a od typowej fauny orientalnej (azjatyckiej), a równocześnie nietypową dla leżącego bardziej na południowy-wschód obszaru w ramach szelfu australijskiego jak Nowa Gwinea. W obszarze tym nazwanym „Wallaceą”, pozostającym poza oboma szelfami, spotyka się organizmy, które nie występują na żadnym $\mathrm{z}$ dwóch sąsiadujących kontynentów ${ }^{2}$. Wspomnieć tu można o tak słynnych gatunkach jak warany z wyspy Komodo, zwane smokami z Komodo,

${ }^{1}$ Charlotte Parry-Crooke (red.), Indonezja, thum. M. Jannasz, seria Fauna i flora świata, Muza SA, Warszawa 1995, s. 14-15.

2 Ibidem, s. 12. 
czy o trochę mniej znanym ptaku z Sulawezi - nogalu hełmiastym (Macrocephalon maleo), nazywanym przez miejscowych maleo, składającym jaja w nagrzanej ziemi, w pobliżu wulkanów i ciepłych źródeł. Kształt tych jaj podważa zasadność powiedzenia, aby nie szukać kwadratowych jajek.

Obok wspomnianych szczególnych przykładów cała Indonezja jest niezwykle bogata w najróżniejsze gatunki flory i fauny, od największego kwiatu świata Rafflesia arnoldi, poprzez lokalne gatunki tygrysów i słoni oraz orangutany, do malutkich wyraków i rybek ozdobnych. To bogactwo, istniejące mimo poniesionych już wielkich strat w naturalnych ekosystemach, stwarza absolutnie pilną konieczność intensywnego ratowania zasobów przyrodniczych kraju.

Łagodny i wilgotny klimat oraz żyzne powulkaniczne gleby sprzyjają urozmaiconej produkcji rolnej - od ryżu, będącego zbożem podstawowym, przez kukurydzę, kassawę, pataty, soję i orzeszki ziemne, do upraw przemysłowych palmy olejowej, tytoniu, kakao, kawy, herbaty, kauczuku, przypraw, różnych warzyw i owoców tropikalnych - od ananasów po duriany. Ziemia kryje niemal wszystkie możliwe surowce kopalne, a przede wszystkim węgiel, gaz naturalny, nikiel, miedź, ropę, cynę, złoto, boksyty i rudy żelaza. Dzięki swoim glebom i zasobom kopalnym Indonezja odgrywa istotną rolę na światowym rynku surowców. Dotyczy to zwłaszcza oleju palmowego, niklu, węgla, kauczuku, kakao i w nieco mniejszym stopniu miedzi oraz gazu naturalnego. Dzięki eksportowi oleju palmowego takie firmy jak Sinar Mas, Wilmar czy Golden Agri-Resources zyskały na znaczeniu w skali światowej, przy czym Wilmar stał się także czołową grupą w sektorze rolno-spożywczym w Azji. Firmy wydobywające i handlujące węglem, jak Bumi Resources i Adaro Energy, również weszły do grupy gigantów światowych w swojej branży³.

Posiadane bogactwa pozwalają przyśpieszać rozwój w okresach światowej koniunktury, ale przy jej spadku i dużym uzależnieniu od ich eksportu mogą tworzyć jednak dodatkowe trudności w rozwoju.

\section{Złożony i dynamiczny pejzaż polityczny}

Indonezja jest państwem jednolitym, republiką parlamentarno-prezydencką, gdzie dominuje władza wykonawcza. Głową państwa jest prezydent, który jednocześnie sprawuje funkcję szefa rządu. Od 2004 r. prezydent jest wybierany w głosowaniu powszechnym. Ustrój został określony przez konstytucję z 1945 r., czyli z okresu proklamowania niepodległości. Była ona w niektórych częściach kilkakrotnie modyfikowana i uzupełniana.

${ }^{3}$ Laurence Danziano, Les pays emergents, Paris 2014, s. 53. 


\section{6}

Indonezja - szanse i wyzwania

Od 2014 r. prezydentem kraju jest Joko Widodo, nazywany w społeczeństwie Jokowi. Zastąpił on dotychczasowego prezydenta Susila Bambanga Yudhoyona (SBY), który od 2004 piastował ten urząd przez dwie kadencje. Mimo wojskowej przeszłości SBY sprawował urząd mało zdecydowanie i zbyt ostrożnie. Jego pierwsza kadencja oceniana była raczej pozytywnie, natomiast w drugiej krytykowano go za chwiejność, kunktatorstwo w kierowaniu popierającą go koalicją, a przede wszystkim za mizerne wyniki $\mathrm{w}$ walce $\mathrm{z}$ korupcją deklarowanej oficjalnie z dużym rozgłosem. W tym za to, że nie ukrócił korupcji we własnym obozie politycznym (Partia Demokratyczna).

W wyborach prezydenckich w lipcu 2014 r. Joko Widodo, popularny gubernator Dżakarty, kandydat wspierany przez koalicję partii, w której główną siłą była Demokratyczna Partia Indonezji - Walka (PDIP), rywalizował z Prabowo Subianto, byłym generałem i zaufanym człowiekiem prezydenta Suharto (w pewnym okresie nawet jego zięciem). Prabowo Subianto wywodzi się z zasłużonej dla niepodległości zamożnej rodziny, a popierała go przede wszystkim partia Golkar, stworzona jeszcze przez Suharto, oraz Gerinda - partia o zabarwieniu nacjonalistycznym, w której powstaniu sam brał udział.

Rywalizacja była symboliczna. Z jednej strony stał Jokowi, wywodzący się z warstwy drobnych producentów (branża meblarska), spoza stolicy (z Solo/Surakarty), niezwiązany w żaden sposób z dotychczasowymi elitami władzy, cieszący się poparciem społecznym za bezpośredniość, ujmujący sposób bycia i umiejętność dialogu ze zwykłymi ludźmi oraz uczciwość, pragmatyzm i sukcesy w zarządzaniu jednostkami administracji lokalnej (od 2010 r. gubernator Dżakarty). Jego kontrkandydatem był przedstawiciel tradycyjnych elit, generał sił specjalnych za czasów Suharto, świetny mówca z dobrym angielskim, utalentowany i energiczny polityk i biznesmen, obiecujący wyborcom zdecydowane i skuteczne zarządzanie krajem i jego awans na arenie międzynarodowej. Ale obciążony przeszłością, w tym znacznymi naruszeniami praw człowieka, podczas operacji prowadzonych na Timorze Wschodnim i w indonezyjskiej części Nowej Gwinei, a nawet w samej stolicy w czasie zamieszek w 1998 r. Po bardzo zaciętej i wyrównanej walce dość wyraźnie wygrał Jokowi, mimo że w ostatnich dniach przed wyborami nawet ustępujący prezydent SBY udzielił nieoczekiwanie poparcia, co prawda dość miękkiego, swojemu koledze z uczelni wojskowej. Prabowo Subianto próbował kontestować wynik na drodze sądowej, zarzucając nieprawidłowości, a nawet oszustwa w wielu punktach wyborczych, ale Sąd Najwyższy potwierdził wyniki i zwycięstwo Jokowi ${ }^{4}$.

${ }^{4}$ Indonesia's Constitutional Court Backs Widodo as Prabowo Subianto's Supporters Stage Protest, Agencies in Jakarta, „South China Morning Post”, 21 sierpnia 2014. 
Nowy prezydent od początku znalazł się w trudnej politycznie sytuacji. W Izbie Reprezentantów, pełniącej właściwe funkcje legislacyjne i kontrolne (druga izba, tzw. Izba Reprezentantów Regionów - samorządowa ze 136 deputowanymi - ma znacznie mniejsze znaczenie), popierająca go koalicja Wspaniała Indonezja (Indonesia Hebat) liczy 207 deputowanych na 560 miejsc i ustępuje znacznie opozycyjnej Koalicji Czerwono-Białej (Merah Putih).

Aktualny skład parlamentu wyłoniono w wyborach w kwietniu 2014 r. na pięcioletnią kadencję i mimo że największą partią została PDIP, kierowana przez byłą prezydent Megawati Sukarnoputri (córkę byłego prezydenta Sukarno), która udzieliła Jokowi silnego wsparcia, układ sił politycznych w parlamencie na razie nie zapowiada, przynajmniej do końca kadencji, przychylnego klimatu dla działań prezydenta.

Specyfika parlamentaryzmu indonezyjskiego pozwala jednak nie wykluczać pewnych zmian w układzie sił politycznych jeszcze podczas tej kadencji. Kierunki tych zmian mogą być różne, co powoduje utrzymywanie się w parlamencie atmosfery nerwowej niestabilności.

Nowy prezydent w swoim programie położył nacisk na rozwój gospodarczy drogą modernizacji i większego urynkowienia oraz szybkiej rozbudowy infrastruktury. Zapowiedział też znacznie lepsze wykorzystanie morskiego potencjału kraju i uczynienie z Indonezyjczyków ponownie narodu morskiego. Obiecał ograniczenie biurokracji, a także spowodowanie sprawniejszego funkcjonowania państwa, w tym lepszych świadczeń i opieki nad najsłabszymi.

Jeszcze przed zaprzysiężeniem, które miało miejsce 20 października 2014 r., nieprzychylne Jokowi siły w parlamencie zablokowały bezpośrednie wybory szefów władz lokalnych na rzecz wprowadzenia wyborów przez lokalne parlamenty. Opozycyjna Koalicja Czerwono-Biała kontroluje 31 prowincjonalnych parlamentów na 34. Dla Jokowi musiało to być szczególnie bolesne, bo sam dzięki bezpośrednim wyborom został burmistrzem Solo, a później gubernatorem Dżakarty ${ }^{5}$.

Istotnym problemem prezydenta jest brak zaplecza politycznego i brak doświadczenia politycznego na poziomie centralnym, na którym dotychczas praktycznie nie działał. Dlatego bardzo istotne stało się dobranie odpowiednich współpracowników, przede wszystkim na szczeblu ministrów. Wybrany na stanowisko wiceprezydenta Jusuf Kalla jest politycznym weteranem o wielkim doświadczeniu na szczeblu centralnym, ale jego znaczenie dla Jokowi zależy przede wszystkim od stopnia jego lojalności. Niezależnie od już pojawiających się różnic zdań z wiceprezydentem nieoczekiwanie sporo trudności od początku sprawia prezydentowi

${ }^{5}$ Editorial, „South China Morning Post”, 5 października 2014. 


\section{8}

Indonezja - szanse i wyzwania

uzgadnianie polityki z jego głównym sojusznikiem - panią Megawati Sukarnoputri, która stara się za pośrednictwem Jokowi realizować swój program partyjny ${ }^{6}$.

Działania prezydenta hamowały również różnego rodzaju skandale i afery. Jedną z nich było odkrycie już na początku kadencji, że Komisja Antykorupcyjna (KPK), odgrywająca od 2002 r. istotną rolę polityczną, w swoim składzie ma osoby podejrzane o korupcję, co doprowadziło do zmiany części członków i ograniczenia jej kompetencji. Pod koniec 2015 r. krajem wstrząsnęła afera podsłuchowa, która wykazała niejasne powiązania opozycyjnego polityka, przewodniczącego parlamentu Setya Novanto z kierownictwem największej na świecie kopalni złota PT Freeport w Papui, należącej do amerykańskiej korporacji Freeport-McMoRan. Zmusiła ona przewodniczącego do rezygnacji w grudniu 2015 r., od stycznia 2016 r. zastąpił go inny opozycyjny polityk Ade Komarudin. Jednak w warunkach indonezyjskich nie pozbawiło to Novanto aspiracji odgrywania dalej czołowej roli w życiu politycznym kraju?

\section{Czynniki wzrostu i pułapki rozwoju}

Po załamaniu gospodarczym, spowodowanym finansowym kryzysem azjatyckim w latach 1997-1998, które było bardzo głębokie (spadek PKB 15\%, spadek wartości rupii o 80\%) i miało dramatyczne konsekwencje polityczne w postaci odejścia prezydenta Suharto, w Indonezji przeprowadzono wiele reform gospodarczych, dzięki którym m.in. zredukowała ona swoje zadłużenie z 83\% PKB w 2001 r. do 25\% w końcu 2011 r. W tym samym roku odnotowała wzrost PKB o 6,45\%, a w 2012 r. o 6,3\%. Warto przypomnieć, że od roku 2000 wzrost PKB był zbliżony do 6\%, co wynikało zarówno z reform, w tym demokratyzacji, jak i z rosnącej roli rynku wewnętrznego, która pozwoliła dość bezboleśnie przejść przez światowy kryzys lat 2008-2009. Pozytywnym czynnikiem było też coraz ważniejsze miejsce Chin jako rosnącego rynku zbytu surowców indonezyjskich ${ }^{8}$. Niestety od 2013 r. tempo wzrostu PKB zaczęło spadać (5,6\%) i prezydent Jokowi objął urząd, kiedy spadło do ok. 5\% w 2014 r. (choć nawet w Azji uznawano to nadal za niezły rezultat). Wynikało to w dużej mierze z oddziaływania czynników zewnętrznych, takich jak spadek światowych cen surowców, ze spowolnienia i restrukturyzacji gospodarki chińskiej oraz z wielu wcześniejszych mało spójnych działań rządu w zakresie polityki handlowej, być może spowodowanych perspektywą wyborów prezydenckich.

${ }^{6}$ Ben Otto, Anita Rachman, Indonesia May Replace Economics Team, Vice President Says, „, The Wall Street Journal”, 24-26 lipca 2015.

7 Special Report Indonesia, „The Economist”, 27 lutego 2016, s. 5.

${ }^{8}$ Françoise Nicolas, Indonesie, une economie ,, decevante”, IFRI - Centre Asie, maj 2015. 
Prezydent Jokowi, zgodnie z obietnicami, już w drugim miesiącu urzędowania podjął ważną decyzję o uporządkowaniu - a w zasadzie o zniesieniu - subwencji na paliwa. Subwencje ciążyły od dawna na budżecie rządu, w przypadku ich utrzymania mogły pochłonąć nawet znacznie ponad 10\% wydatków rządowych w następnym roku. Mimo ograniczonych protestów pewnych grup ludności decyzja została przyjęta ze zrozumieniem $\mathrm{w}$ społeczeństwie oraz pozytywnie w sferach biznesowych, co znalazło odbicie na giełdzie i zostało uznane za sygnał, że prezydent jest zdecydowany realizować politykę reform ${ }^{9}$. Środki uwolnione z finansowania subwencji pozwoliły prezydentowi na uruchomienie programów z zakresu ubezpieczeń zdrowotnych, finansowania bezpłatnej edukacji i zasiłków dla najbiedniejszych ${ }^{10}$. Szczególnie ambitne były działania w dziedzinie ochrony zdrowia. Już w roku 2014 przystąpiono do wprowadzania powszechnych ubezpieczeń zdrowotnych. Cała ludność ma być objęta ubezpieczeniem w roku $2019^{11}$. Wydatki na te programy okazały się jednak większe niż uzyskane środki i deficyt budżetowy niebezpiecznie zbliżył się do 3\% PKB (2,8\% w 2015 r.).

Drugim kierunkiem działania Jokowi, zresztą zgodnie z zapowiedziami, była modernizacja i rozbudowa infrastruktury transportowej, która od kryzysu 1997 -1998 prawie nie była modernizowana. Chodzi o budowę nowych portów morskich (6 głębokowodnych portów dla skokowej poprawy komunikacji pomiędzy głównymi wyspami i 22 mniejszych), lotnisk (62 nowe lotniska, aby ich liczba wzrosła do prawie 300), nowych linii kolejowych i dróg oraz o modernizację już istniejących, tak aby wyraźnie skrócić czas obsługi ruchu towarów i osób. Rozbudowana ma być również baza dla produkcji energii elektrycznej (20\% ludności nie ma jeszcze dostępu do energii elektrycznej, ale równocześnie mieszkańcy Dżakarty korzystają proporcjonalnie najwięcej na świecie z łączności telefonii komórkowej). Symboliczne znaczenie ma rozpoczęcie budowy autostrady Trans Sumatra, która ma być gotowa w 2019 r., i przyśpieszenie prac nad autostradą Trans Java, która ma być oddana do końca 2017 r. We wstępnych założeniach ok. 30\% wydatków na infrastrukturę będzie finansowanych ze źródeł prywatnych. Rząd przewiduje także istotne skorzystanie z pomocy Banku Światowego, Azjatyckiego Banku Rozwoju (ADB), a także z japońskich funduszy pomocowych. Do rywalizacji o miejsce w Indonezji w rozbudowie infrastruktury dołączyli również Chińczycy, którzy na początek w ostrej walce konkurencyjnej pokonali Japończyków i uzyskali kontrakt na budowę szybkiej linii kolejowej na trasie Dżakarta - Bandung

\footnotetext{
9 Fuel's Errand, „The Economist”, 22 listopada 2014, s. 50.

${ }^{10}$ A Good Scrap; Full of Promise, "The Economist”, 10 stycznia 2015, s. 46, 52.

${ }^{11}$ Maria Kruczkowska, Indonezja stawia na zdrowie narodu, „Gazeta Wyborcza”, 31 maja 2016.
} 
o długości ok. $150 \mathrm{~km}^{12}$. Zainteresowana rozbudową infrastruktury Indonezja dołączyła jako jedno z pierwszych państw regionu do chińskiej inicjatywy utworzenia Azjatyckiego Banku Inwestycji Infrastrukturalnych (AIIB). Podniesienie wydatków na szeroko rozumianą infrastrukturę zostało dobrze przyjęte w kraju, jak i wśród zagranicznych ekspertów oraz biznesmenów. Oczekuje się, że znacznie polepszona infrastruktura pozwoli na obniżenie kosztów logistyki, a w konsekwencji obniży ceny oraz ułatwi wymianę z zagranicą. Powinno to przynieść szybszy wzrost gospodarczy.

W swoim programie Jokowi bardzo wyraźnie zaakcentował konieczność powiązania rozwoju kraju z aktywizacją gospodarki morskiej. W inauguracyjnym przemówieniu prezydent zapowiedział skończenie z polityką odwracania się od obszarów morskich. Kilka tygodni później w pierwszym wystąpieniu na szczycie przywódców ASEAN w Mjanmie zapowiedział całkowitą zmianę podejścia do spraw morskich, poprawę połączeń wewnętrznych i zewnętrznych, m.in. poprzez budowę portów i połączeń promowych, rozwój przemysłu rybnego, innymi słowy - stworzenie z Indonezji centrum gospodarki morskiej. Zapowiedział także zdecydowane reagowanie na nielegalne połowy i inne formy naruszania suwerenności kraju na obszarze morskim. Rybołówstwo indonezyjskie, mimo że żyją z niego dziesiątki milionów ludzi, opiera się na małych prymitywnych jednostkach rybackich i boryka się z brakiem chłodni do składowania połowów oraz brakiem nowoczesnej bazy przetwórczej. Eksport w tej branży ustępuje np. eksportowi Tajlandii, której obszary morskie są bez porównania mniejsze. Prawdziwą plagą jest kłusownictwo na wodach indonezyjskich, prowadzone zarówno przez partnerów z ASEAN, głównie statki rybackie z Tajlandii i Wietnamu, jak i często przez wielkie statki przetwórnie z Chin, Korei Południowej, Japonii i Tajwanu. Straty Indonezji z tego powodu oceniane były na ponad $3 \mathrm{mld}$ dol. rocznie (są też szacunki dużo większe). Do niedawna statki kłusowników działały niemal bezkarnie zarówno ze względu na słabość straży przybrzeżnej, jak i marynarki wojennej Indonezji, ale także brak zdecydowanej polityki rządu w tym zakresie ${ }^{13}$. Na osobiste polecenie nowego prezydenta straż przybrzeżna i marynarka wojenna przeprowadziły wiele spektakularnych akcji zatrzymań, a nawet zatopień statków kłusowników (po ewakuacji załóg). Wobec morskiej słabości kraju nie rozwiąże to oczywiście problemu, ale zapewne ograniczy kłusownictwo morskie na wodach indonezyjskich i prawdopodobnie skłoni inne strony do rozmów w sprawie przynamniej uzgodnienia ewentualnych kwot połowowych. Równocześnie władze indonezyjskie wy-

${ }_{12}$ Indonesian Gov't, Joint Venture Ink Deal on High-speed Railway Concession, Xinhua, „China Daily", 17 marca 2016.

13 Fishing Trips, „The Economist”, 3 stycznia 2015. 
raziły zainteresowanie współpracą i zagranicznymi inwestycjami w rybołówstwo i szerzej w gospodarkę morską.

Najważniejszy jednak w realizacji planów Jokowi okazał się ogólny klimat dla działalności biznesowej, w tym dla inwestycji zagranicznych. Sprawa zagranicznych inwestorów budzi duże wątpliwości i wahania w społeczeństwie, które pamięta zarówno panoszenie się obcych koncernów, szczególnie w pierwszym okresie rządów Suharto pod koniec lat 60. XX w., jak również masową ucieczkę obcych firm i kapitałów w czasie azjatyckiego kryzysu finansowego 1997-1998, sprowokowanego zresztą przez amerykańskich spekulantów finansowych, co spowodowało wyrzucenie na bruk tysięcy ludzi zatrudnionych w firmach zagranicznych. Niezbyt przychylne reakcje aparatu państwowego wobec inicjatyw firm zagranicznych wynikają także z dość niespójnych działań poprzedniej ekipy, np. wydania zakazu eksportu nieprzerobionych surowców mineralnych. Eksport ten następnie został znacznie ograniczony w wyniku nacisków zagranicznych koncernów, co wzmocniło przekonanie o ich negatywnym i nadmiernym wpływie na politykę rządu. Powyższe niechętne nastroje, niezależnie od ich oceny, obiektywnie utrudniają Jokowi prowadzenie probiznesowej polityki.

Obok czynnika „obyczajowo-psychologicznego” możliwości reformatorskie rządu ograniczał wspomniany już światowy trend spadku popytu na surowce, a w związku z tym cen na te towary, których udział w eksporcie sięgał nawet $60 \%$. Przykładowo węgiel, który według Banku Światowego stanowi ok. 14\% eksportu Indonezji i ok. $17 \%$ światowego importu tego surowca, potaniał z ok. 150 dol. za tonę w 2011 r. do 50 dol. w 2015 r.

Innego rodzaju ogranicznikiem działań rządu stał się niewydolny od dawna system podatkowy. Zaledwie ok. $27 \mathrm{mln}$ obywateli płaci podatki, i to w większości znacznie zaniżone ${ }^{14}$. Powoduje to spore uszczuplenie możliwości finansowych rządu. Polityka modernizacji napotyka również bariery wynikające z ogólnie niskiego poziomu szkolnictwa, co powoduje brak kwalifikowanego personelu chociażby w usługach. Ocenia się, że w regionie uczniowie indonezyjscy ustępują poziomem wykształcenia nie tylko uczniom z bogatego Singapuru, ale i z Wietnamu, gdzie dochód na głowę stanowi tylko trzy piąte dochodu indonezyjskiego ${ }^{15}$. Kolejnym czynnikiem, który wprawdzie działa na rzecz wzrostu gospodarczego, ale ogranicza swobodę wyboru polityki przez rząd, jest pojawianie się co roku ok. 2,5 mln młodych ludzi na rynku pracy. Z kolei zagranicznych biznesmenów, w tym inwestorów, odstraszają trudności z wejściem na rynek, które wynikają zarówno z przepisów, jak i z długiego czekania na odpowiednie pozwolenia. Nie ułatwiają tego niejasne i czasem sprzeczne przepisy, długie terminy załatwiania wszystkich

${ }^{14}$ Special Report Indonesia, s. 8.

15 School's in, „The Economist”, 13 grudnia 2014, s. 52. 
spraw, częsta korupcja, a także wspomniana słaba infrastruktura, powodująca zatory i opóźnienia w ruchu towarów.

Mimo ograniczeń i zagrożeń prezydent Jokowi od czasu objęcia urzędu konsekwentnie inspiruje i nadzoruje wdrażanie działań mających poprawić atmosferę dla biznesu, umocnić rolę rynku i wprowadzić ułatwienia dla zagranicznych inwestorów. Po upływie ponad półtora roku widać, że główny nacisk kładzie na rozwój infrastruktury i bazy energetycznej, na co przewidziana jest znaczna kwota 450 mld dol., której wydatkowanie ma nastąpić w najbliższych latach. Dzięki lepszym połączeniom transportowym większe możliwości rozwoju mają uzyskać regiony dotychczas znacznie mniej rozwinięte niż centralna dla gospodarki wyspa Jawa. Rozwój ma być też bardziej zrównoważony. Przy dążeniu do wspierania zagranicznych inwestorów i zapewnieniu im możliwości działania widoczne jest również, że Jokowi, świadomy nastrojów społecznych, uważa, że kraj powinien utrzymać kontrolę nad eksploatacją swoich zasobów naturalnych.

Od 26 stycznia 2015 r. wyspecjalizowana instytucja centralna Indonesian Coordination Board (BKPM) rozpoczęła wdrażanie procedur mających zapewnić zagranicznym inwestorom łatwiejsze załatwianie formalności koniecznych do podjęcia działalności. Dzięki nowemu systemowi zagraniczny inwestor w jednym miejscu może załatwić sprawy, które niekiedy wymagałyby uzyskiwania oddzielnych zezwoleń od nawet 22 ministerstw i instytucji centralnych. Według źródeł indonezyjskich dzięki wspomnianemu rozwiązaniu okres oczekiwania na końcowe zezwolenie skrócił się ze średnio 260 dni do 90 dni. Skrócono nawet niezwykle długie formalności (około trzech lat) wymagane do zgody na budowę elektrowni ${ }^{16}$.

Rok 2015 przyniósł pewien postęp w postrzeganiu Indonezji w świecie, w tym przez zagranicznych inwestorów, a także dynamiczny (7,2\%) wzrost przyjazdów zagranicznych turystów do prawie 10,5 mln. Napływ inwestycji zagranicznych, prawdopodobnie w związku ze wspomnianymi krokami, był największy wśród państw Azji Południowo-Wschodniej. Stanowisko w sprawie inwestycji zagranicznych jednak nawet w rządzie nie było jednoznaczne. Otwarto całkiem pokaźną listę sektorów, gdzie do tej pory zakazane lub ograniczone były inwestycje zagraniczne, takie jak produkcja kauczuku, kinematografia i restauracje, ale natychmiast zamknięto kilka innych. W celu umocnienia realizacji wytyczonych zadań prezydent dokonał w sierpniu 2015 r. rekonstrukcji gabinetu, obejmującej szczególnie resorty gospodarcze. Nowi ministrowie bardziej niż ich poprzednicy odpowiadają jego zapowiedziom z okresu kampanii wyborczej, kiedy mówił o rządzie ekspertów z dużym doświadczeniem w relacjach z zagranicą. Ich głównym zadaniem jest energiczniejsze reformowanie gospodarki, umacnianie otwarcia gospodarki na świat i przyciąganie zagranicznych inwestorów.

${ }^{16}$ The Economy with Remarkable Adaptability, Republic of Indonesia, 2016, s. 7. 
W 2015 r. wzrost PKB wyniósł 4,75\%, przy utrzymaniu się rezerw walutowych na poziomie ponad 102 mld dol. i zadłużeniu na poziomie $26 \%$ PKB. Indonezja pozostała dziesiątą gospodarką świata, zajmującą wysokie miejsce w G20 pod względem tempa wzrostu. Na rok 2016 rząd przewiduje wzrost w granicach $5,2-5,6 \%$ przy inflacji poniżej $4 \%{ }^{17}$. W świetle wspomnianych zmian w resortach gospodarczych i widocznego osobistego zaangażowania prezydenta proces modernizacji gospodarki powinien trochę przyśpieszyć, przy czym wiele będzie zależało od sytuacji gospodarczej na świecie i w regionie. Znawcy Indonezji lubią mówić, że wyniki jej gospodarki są zawsze gorsze, niż oczekują tego optymiści, i zawsze lepsze, niż to przewidują pesymiści.

\section{Demony trapiq̨ce Indonezję}

Bogactwa naturalne, wyspiarskie położenie i wielka różnorodność mieszkańców od dawna sprzyjały tendencjom separatystycznym. Wykorzystywały to oczywiście również siły zewnętrzne. Jeszcze długo po opuszczeniu Indonezji dawne mocarstwo kolonialne inspirowało lub wspierało bunty i rewolty, szczególnie na terenach odległych od faktycznego centrum na Jawie, a więc na Molukach, Sumatrze czy Sulawesi. Rewolty te, jak również liczne inicjatywy domorosłych separatystów, kończyły się niepowodzeniami i nie doprowadziły do podziału kraju.

Poważnym wyzwaniem dla Indonezji była sprawa Timoru Wschodniego. Terytorium - pozostałość po dawnych koloniach portugalskich - było od $1974 \mathrm{r}$, wstrząsane konsekwencjami rewolucji goździków w samej metropolii. Po nieoczekiwanym wycofaniu się Portugalczyków władza wydawała się nieuchronnie przechodzić tu w ręce ugrupowań skrajnie lewicowych. Podczas oficjalnej wizyty prezydenta Stanów Zjednoczonych Geralda Forda i sekretarza stanu Henry'ego Kissingera w Dżakarcie na początku grudnia 1975 r. prezydent Indonezji Suharto otrzymał zielone światło dla swych działań. Dwa dni później, 7 grudnia, wojska indonezyjskie wkroczyły na teren Timoru Wschodniego. USA i Wielka Brytania udzieliły także wkrótce wsparcia w sprzęcie lotniczym przeznaczonym do działań antypartyzanckich ${ }^{18}$. Walki były nieoczekiwanie bardzo ciężkie, ale ostatecznie znacznie przeważające liczebnie wojska indonezyjskie opanowały kraj, który został w 1976 r. formalnie wcielony do Indonezji. Partyzantka działała jednak nadal z różnym nasileniem. W ONZ, głównie za sprawą Portugalii, aneksja Timoru Wschodniego nie została uznana. Po upadku Suharto jego następca Bacharuddin

17 Ibidem, s. 17, 55.

18 Sonny Inbaraj, East Timor - Blood and Tears in ASEAN, Silkworm Books, Chiang Mai 1995, s. VIII, 6. 
Indonezja - szanse i wyzwania

Jusuf Habibie zgodził się na referendum na Timorze Wschodnim w 1999 r. pod nadzorem ONZ, w którym 78,5\% ludności poparło niepodległość. Kraj przejęła czasowo w zarząd misja ONZ, a 20 maja 2002 r. ogłoszono niepodległość Timoru Wschodniego. Koszt tych dramatycznych wydarzeń dla obu stron był wysoki. W Timorze Wschodnim, który w momencie wejścia wojsk indonezyjskich liczył ok. 650 tys. mieszkańców, liczbę strat ludzkich ocenia się tylko do drugiej połowy lat 90. na ok. 200 tys. ludzi ${ }^{19}$. Indonezja, obok bliżej nieokreślonej, ale znacznej liczby poległych i rannych żołnierzy oraz wysokich kosztów materialnych, poniosła dramatyczne straty prestiżowe w ONZ i szerzej w opinii międzynarodowej, gdyż jej siły zbrojne były oskarżane o bezwzględne pacyfikacje, masowe zabójstwa i tortury stosowane wobec miejscowej ludności. Wydaje się, że dramatyczne doświadczenia z Timorem Wschodnim mają do dziś pewien wpływ na myślenie klasy politycznej i dowództwa sił zbrojnych.

Przykładem wpływu tych doświadczeń może być rozwój sytuacji w prowincji Aceh na północnym krańcu Sumatry. Prowincję tę podbili Holendrzy jako ostatnią, dopiero na początku XX w., jednak nigdy jej w pełni nie kontrolowali. Na terenach, gdzie od dziesięcioleci (od końca lat 70.) trwały walki sił rządowych z miejscowymi powstańcami, żądającymi niepodległości, m.in. w imię bardzo konserwatywnej wersji islamu, impulsem do rozmów było straszliwe tsunami w grudniu 2004 r., które pochłonęło ponad 150 tys. ofiar, a straty materialne były olbrzymie. Dwa dni po tsunami Ruch Wolnego Aceh (GAM) pierwszy ogłosił wstrzymanie działań bojowych, co zostało potwierdzone także przez stronę rządową. Dzięki kontaktom wynikającym z potrzeb akcji ratunkowej i pomocowej udało się zainicjować rozmowy pomiędzy stronami. W doprowadzeniu do rozmów pokojowych $\mathrm{i}$ ich powodzeniu znaczącą rolę odegrała Unia Europejska, która obok bardzo istotnej pomocy dla ludności Aceh potrafiła zaskarbić sobie zaufanie rebeliantów z GAM. W wyniku negocjacji w sierpniu 2005 r. podpisano w Helsinkach porozumienie pokojowe, w którym władze w Dżakarcie uznały specjalny status prowincji (jedyna w kraju, w której oficjalnie stosuje się prawo szariatu), ogłosiły amnestię dla członków GAM i wycofały znaczną część wojsk w zamian za złożenie broni i rezygnację z niepodległości przez GAM. Rok później w wyborach lokalnych zdecydowanie wygrało młode pokolenie przywódców ruchu, które zadeklarowało ostateczne zerwanie z separatyzmem i włączyło się w pełni w system polityczny Indonezji. Od tego czasu sytuacja w prowincji jest normalna.

Szczególnie złożony i trudny jest problem zachodniej części Nowej Gwinei, nazywanej Irian Jaya, a administracyjnie podzielonej obecnie na dwie prowincje: Papuę i Zachodnią Papuę. W 1949 r. w porozumieniu o przyznaniu niepodległości Indonezji przez Holandię ta druga wymogła dłuższe utrzymanie kontroli nad

19 Ibidem, s. 11. 
tym terytorium. W wyniku polityki „konfrontacji” prezydenta Sukarno, a przede wszystkim w wyniku nacisków USA, obawiających się przejścia Indonezji do obozu komunistycznego, w 1962 r. wymuszono na Holandii przekazanie terytorium pod administrację ONZ, a ta w 1963 r. przekazała je Indonezji. W 1969 r. zgromadzenie szefów plemion papuaskich (ponad tysiąc tzw. elektorów akceptowanych, a w większości nawet wyznaczonych przez władze), pod silną presją Dżakarty, potwierdziło włączenie terytorium do Indonezji. W rzeczywistości na tym terenie od 1963 r. działał Ruch Wolnej Papui (OPM), który bez większego powodzenia próbował od czasu do czasu działań partyzanckich i z niewiele większym sukcesem starał się o wsparcie zagraniczne, ograniczające się jednak nadal do sympatii małych państewek wyspiarskich na Pacyfiku i niektórych środowisk z sąsiedniego państwa Papua-Nowa Gwinea.

Pewne nadzieje na zmianę sytuacji dało referendum niepodległościowe na Timorze Wschodnim w 1999 r., a później krótki okres prezydentury Abdurrahmana Wahida, który przewidywał przyznanie terytorium autonomii. Jego następczyni Megawati Sukarnoputri, przyznała prowincjom bardzo ograniczoną autonomię, w tym prawo do własnej flagi, obok flagi państwowej, oraz udziały w dochodach z eksploatacji surowców. Wszystkie ważne decyzje zapadały jednak w Dżakarcie. Spowodowało to potępienie i odrzucenie tych kroków przez OPM.

W praktyce w obu prowincjach bez ograniczeń twardą ręką rządzą siły zbrojne i urzędnicy przysłani ze stolicy. Niezależni dziennikarze przez wiele lat nie byli tam mile widziani ${ }^{20}$. Od lat realizowany jest też program przesiedleń ludności z innych wysp, szczególnie z nadmiernie zaludnionej Jawy i Madury. W tej sytuacji Papuasi już obecnie są w mniejszości, a w 2030 r. mogą stanowić już tylko 15\% ludności obu prowincji ${ }^{21}$.

W czasie kampanii wyborczej Jokowi wiele uwagi poświęcił obu prowincjom, a w jego otoczeniu, nawet już po wyborach, znaleźli się ludzie związani z Papuą, co mogło zapowiadać nową politykę. Dotychczasowe działania prezydenta nie przyniosły jednak na razie istotnych zmian poza uwolnieniem dwóch zatrzymanych francuskich dziennikarzy, którzy zbierali materiały w terenie bez stosownych pozwoleń, i poza zapowiedzią pewnej liberalizacji w tym zakresie. Przeważają opinie, że na przeszkodzie nowego otwarcia stoją zarówno interesy, nastroje i przekonania elit indonezyjskich, w tym sił tak ważnych dla Jokowi, jak szefowa największej popierającej go partii PDIP, była prezydent Megawati Sukarnoputri, i konserwatywny wiceprezydent Jusuf Kalla, ale także interesy wysokich dowódców sił

20 Jacek Pawlicki, Indonezyjscy Papuasi chca być na swoim, „Gazeta Wyborcza”, 30 czerwca-1 lipca 2012.

${ }_{21}$ Philippe Celerier Pataud, Les Papous minoritaires en Papouasie, „Le Monde diplomatique”, luty 2015 . 
zbrojnych. Dodatkowo dochodzi polityka wielkiego koncernu amerykańskiego Freeport-McMoRan, który w obronie swoich znacznych dochodów wykorzystuje potężne koneksje w administracji amerykańskiej i w najbardziej wpływowych kołach światowego biznesu, aby sytuacja pozostała bez zmian ${ }^{22}$.

Nie wydaje się, aby szybko znaleziono rozwiązanie tej trudnej i bolesnej sprawy, nawet jeżeli prezydent Jokowi umocni swoją pozycję polityczną. Na przeszkodzie, obok wspomnianych wielkich emocji i spraw prestiżowych oraz partykularnych interesów osób (cywilnych i wojskowych) zaangażowanych w zarządzanie oboma prowincjami, stoją obiektywnie wielkie bogactwa naturalne już eksploatowane jak miedź, złoto i gaz naturalny, ale i potencjalne (obie prowincje zostały tylko częściowo zbadane geologicznie), które już mają lub mogą mieć duże znaczenie dla gospodarki kraju i dla wielkich koncernów międzynarodowych. Drugim decydującym czynnikiem są głębokie, trudne do przezwyciężenia różnice pomiędzy rdzennymi mieszkańcami a ludnością napływową, często osiedlaną w ramach wspomnianych operacji specjalnych. Obie te grupy różni wszystko - pochodzenie etniczne, religia, kultura, cywilizacja i tradycja historyczna, na co nakłada się głębokie poczucie krzywdy Papuasów, że nie rządzą w kraju swoich przodków.

Uzasadniona chyba jest ocena, że jeżeli nie zostaną podjęte nowe działania przynajmniej częściowo wychodzące naprzeciw oczekiwaniom rdzennej ludności, sprawa Papui będzie co jakiś czas zarówno tworzyć napięcia wewnętrzne, jak i obciążać międzynarodową pozycję Indonezji.

Wyznawcy islamu w Indonezji stanowią ponad $86 \%$ społeczeństwa. Społeczność ta jest podzielona pod wieloma względami, ale chyba najważniejszy to podział na santri - ściśle praktykujących i abangan - tylko formalnie zaliczających się do wyznawców islamu. Tradycyjnie obie grupy były liczebnie dość wyrównane, dopiero ostatnie lata przyniosły szybki wzrost liczby santri. Islam odegrał ważną rolę w walce $\mathrm{z}$ Holendrami o niepodległość, ale w nowym państwie władzę przejęli świeccy nacjonaliści i islam został tylko jednym z pięciu oficjalnie uznanych wyznań. Siły skrajnie islamistyczne, chociaż w mniejszości, wkrótce podjęły walkę z rządem, pod hasłem tworzenia państwa islamskiego, a ruch przybrał nazwę Darul Islam i rozprzestrzenił się szczególnie na zachodniej Jawie, północnej Sumatrze i południowym Sulawesi. Rebelia, najsilniejsza pod koniec lat 50. XX w., wygasła na początku następnej dekady, choć i w późniejszych latach dawała o sobie znać pojedynczymi aktami przemocy ${ }^{23}$. Ożywienie skrajnych ruchów islamskich nastąpiło po odejściu Suharto w 1998 r., wtedy to do kraju wrócili z Malezji radykalni duchowni islamscy, w tym Abu Bakar Ba'asyir. Był to główny inspira-

${ }^{22}$ Ibidem.

${ }^{23}$ Damien Kingsbury, Violence in Between. Conflict and Security in Archipelagic Southeast Asia, ISEAS/Monash University Press, Clayton 2005, s. 11. 
tor utworzenia jeszcze w Malezji organizacji Dżama’a Islamija (Jemaah Islamiyah, JI), stawiającej sobie za cel obalenie siłą świeckiego państwa i utworzenie kalifatu Azji Południowo-Wschodniej24 . Organizacja powiązana z Al Kaidą przystąpiła do przygotowania zakrojonych na szeroką skalę działań terrorystycznych, obejmujących zarówno Indonezję, jak i Filipiny, ale także próbowała zainicjować akty terroru w Singapurze, Tajlandii i Kambodży.

Przez kilka pierwszych lat XXI w. Dżama'a Islamija dokonała w Indonezji wielu dużych zamachów terrorystycznych, z których najtragiczniejszy w skutkach był ten na Bali w październiku 2002 r., wymierzony w gości dwóch nocnych klubów. Zginęły wówczas 202 osoby, a ok. 700 zostało rannych. Zamach wykazał wysoki stopień zagrożenia terrorystycznego w Indonezji i zmusił władze do oficjalnego przyznania, że w kraju działa rodzima organizacja terrorystyczna. Od tego momentu władze podjęły energiczne działania antyterrorystyczne, wspierane m.in. przez Australię, której obywatele stanowili przeważającą część ofiar (zginęła też obywatelka polska, dziennikarka „Gazety Wyborczej” Beata Pawlak). Mimo istotnego zwiększenia działań antyterrorystycznych zamachy się powtarzały, choć ich skala była mniejsza niż w 2002 r. Za ostatni z zamachów z tej serii, zorganizowany przez szeroko rozumianą Dżama'a Islamija, uznano zamach w 2009 r. na dwa hotele firm zachodnich w Dżakarcie. Obraz działalności i powiązań Dżama’a Islamija komplikował fakt, że w tym okresie jej ,aktywiści” byli również zaangażowani w starcia między radykałami islamskimi a chrześcijanami na Molukach, szczególnie w mieście Ambon. W Ambon niejasne były układy władz lokalnych oraz relacje różnych służb wojska i policji ze stronami konfliktu, choć na ogół islamiści, najczęściej osadnicy z innych wysp, popierani byli dyskretnie przez niektóre służby specjalne wojska, a chrześcijanie przez policję bardziej powiązaną z rdzenną ludnością miasta ${ }^{25}$.

Dżama'a Islamijja nie była jedyną organizacją terrorystyczną działającą w tym okresie w Indonezji. Do bardziej aktywnych można zaliczyć Laskar Jihad, Laskar Mujahidin czy Laskar Jundullah. Grupy te były szczególnie aktywne w czasie ataków na społeczności chrześcijańskie na Molukach i w środkowym Sulawesi. Na ogół nie miały jednak ambicji działania na skalę krajową czy międzynarodową.

Energiczne antyterrorystyczne działania władz stopniowo przynosiły efekty. Duży był w tym udział jednostki specjalnej Densus 88, powołanej do bezpośredniego zwalczania terroryzmu, i utworzonej w 2010 r. Narodowej Agencji Zwalczania Terroryzmu, organu o bardzo szerokich kompetencjach. Pod koniec pierwszego dziesięciolecia XXI w. niemal wszyscy najaktywniejsi terroryści Dżama’a Islamija i innych grup albo już nie żyli, albo przebywali w więzieniach, włącznie

\footnotetext{
${ }^{24}$ Ibidem, s. 19-20.

25 Ibidem, s. 231-254.
} 
$\mathrm{z}$ inspiratorem i ideologiem terroru islamskiego Abu Bakarem Ba'asyirem, odsiadującym karę 15 lat więzienia za wspieranie obozu szkoleniowego terrorystów ${ }^{26}$. Władze miały do czynienia już tylko z rozproszonymi grupami i grupkami radykalnych islamistów, próbującymi organizować improwizowane akty terroru.

Szokiem dla władz i opinii publicznej był zamach terrorystyczny w Dżakarcie 14 stycznia 2016 r., który szczęśliwe nie spowodował wielu ofiar (cztery osoby) poza samymi terrorystami, ale doprowadził do prawdziwej walki ulicznej w centrum 10-milionowego miasta. Odpowiedzialność za zamach wzięło Państwo Islamskie, które zresztą wcześniej zapowiadało tworzenie odległego kalifatu w kraju, gdzie jest najwięcej muzułmanów. Ustalono, że na terenie Syrii islamiści utworzyli batalion bojowników mówiących językiem malajskim, tzw. Katiba Nusantara. Ocenia się, że może w nim walczyć do 300 bojowników z Indonezji, niewiele w stosunku do liczebności radykalnych islamistów w kraju ${ }^{27}$. Władze zareagowały na zamach zdecydowanie, natychmiast przeprowadzając serię aresztowań i rewizji w całym kraju, oraz zapowiadając zaostrzenie polityki wobec sympatyków dżihadu $^{28}$. Równocześnie władze nasiliły starania, aby mobilizować do ograniczania wpływu radykałów na umiarkowanych islamskich przywódców religijnych. Należy tu nadmienić, że Indonezja od 2004 r. konsekwentnie stara się inicjować dialog pomiędzy różnymi kierunkami islamu oraz dialog z innymi religiami, co czasem wywołuje różnice stanowisk z niektórymi państwami arabskimi.

Specjaliści zajmujący się problematyką terroryzmu raczej nie widzą obecnie dużych możliwości ożywienia terroryzmu w Indonezji m.in. ze względu na osłabienie grup terrorystycznych, zdecydowane wielopłaszczyznowe działanie rządu, dobrą współpracę Indonezji z innymi partnerami w zwalczaniu terroryzmu oraz pewne zniechęcenie nawet radykalnych środowisk islamskich do działań prowadzących do strat głównie wśród samych wyznawców islamu ${ }^{29}$.

Podzielając w ogólnej wymowie powyższą ocenę, autor uważa jednak, że w dłuższym okresie niebezpieczeństwo kryje się w stopniowym wzroście liczby zwolenników radykalnego islamu. Wiąże się to m.in. ze stałym i intensywnym oddziaływaniem prowadzonym przez oficjalne placówki i agendy przede wszystkim Arabii Saudyjskiej, ale też niektórych innych państw arabskich, które poprzez zachęty finansowe, różnego rodzaju naciski, a często szantaż, promują tworzenie radykalnych szkół koranicznych, budowę lub przebudowę meczetów (na styl bliskowschodni)

26 Joseph Chinyong Liow, Dictionary of the Modern Politics of Southeast Asia, hasło: Jemaah Islamiyah, Routledge, London 2015, s. 205-206.

${ }^{27}$ Eric Frecon, Terrorisme en Asia du Sud-Est, „Diplomatie”, Paris, kwiecień-maj 2016.

${ }_{28}$ Madjid Zemouky, L'Indonesie - Terre de Mission de l'Etat Islamique, „Le Monde”, 14 stycznia 2016.

29 Wojciech Tomaszewski, Dlaczego terroryści uderzyli w Indonezję, Centrum Studiów Polska - Azja, 9 marca 2016, www.polska-azja.pl. 
i zmuszają imamów do głoszenia radykalnego wahabickiego islamu. Placówki dyplomatyczne tych krajów inspirują i finansują rzekomo oddolne ruchy na szczeblach powiatowych, które domagają się przekształcania świeckiej administracji rządowej w aparat kierujący się zasadami szariatu. Inicjatywy takie mają miejsce najczęściej na południowym Sulawesi, ale także na Jawie. Sprzyja to szerzeniu się w niektórych kołach atmosfery zrozumienia dla idei dżihadu.

Drugim niebezpiecznym zjawiskiem sprzyjającym odradzaniu się terroryzmu, jest tradycja przyjazdów terrorystów arabskich do Indonezji na swego rodzaju „urlopy wypoczynkowe”, w tym w celu zawierania kilkumiesięcznych małżeństw islamskich z miejscowymi kobietami. W czasie tych pobytów, niejako przy okazji, „urlopowicze” inspirują i szkolą miejscowych do tworzenia struktur terrorystycznych. Najczęściej są to fanatyczni bojownicy z prowincji Hadramaut w Jemenie, ale również z innych krajów arabskich.

W przypadku pojawienia się nowych warunków, np. gwałtownego osłabienia struktur państwa i pogorszenia się sytuacji gospodarczej, czynniki te mogą prowadzić do ponownego znacznego ożywienia terroryzmu islamskiego.

Siły zbrojne są bez wątpienia, obok banku centralnego, najsolidniejszą, najlepiej zorganizowaną i najskuteczniejszą państwową strukturą organizacyjną w Indonezji. Autor niejednokrotnie miał okazję przekonać się o tym podczas swojej misji w Indonezji, w kontaktach z dowództwem sił zbrojnych i z dowództwami poszczególnych ich rodzajów. Kierownictwo sił zbrojnych tradycyjnie należy do najbardziej wpływowych elit i sił w kraju i cieszy się dużym autorytetem. Wynika to jeszcze z szacunku i popularności zdobytej w okresie walk o niepodległość, dobrego poziomu wykształcenia na tle dość przeciętnego ogólnego poziomu, a także z pewnej niezależności wojska od budżetu rządowego. Kraj przeznacza oficjalnie na obronę nieco mniej niż 1\% PKB dla utrzymania sił zbrojnych liczących ok. 390 tys. ludzi. Wydatki te są jednak w istocie większe, ponieważ siły zbrojne korzystają z wpływów z wielu zakładów i instytucji gospodarczych, które zaraz po uzyskaniu niepodległości zostały im przekazane zamiast opłaty żołdu i którymi wojsko zarządza do chwili obecnej, a których dochody nie są uwzględniane w budżecie obrony. Posiadanie własnego sektora gospodarczego zwiększa niezależność wojskowych, a próby ograniczenia tego zjawiska nie dały rezultatów. Oddzielną kwestią są przypadki pozaprawnych działań wojskowych, m.in. w takich sferach jak nielegalny wyrąb lasów czy monopolizowanie ochrony obiektów wielkich koncernów zagranicznych, a nawet nielegalny handel bronią. Oddzielnym ważnym czynnikiem umacniającym pozycję sił zbrojnych jest koncepcja tzw. $d w i$ fungsi (podwójnej roli). Jej korzenie sięgają początków niepodległości, ale pozostaje ona ciągle aktualna. Siły zbrojne nie tylko zapewniają bezpieczeństwo, ale spełniają funkcję społeczno-polityczną, szczególnie w momentach zagrożenia. W tym 
celu dysponują siecią równoległej rezerwowej administracji, która może w każdym momencie przejąć kierowanie poszczególnymi regionami i organizowanie obrony terytorialnej. Daje to im często tytuł do ingerowania w sprawy wewnętrzne na szczeblu powiatu czy prowincji. Dzięki tej mocnej pozycji siły zbrojne czują się wysoce odpowiedzialne za sytuację w kraju. W konsekwencji jednak również są bardziej skłonne do interwencji w sprawy wewnętrzne w przypadku wzrostu zagrożeń, ale niekiedy również w obronie własnych interesów.

\section{Szanse na sukces}

Ważnym czynnikiem wpływającym na perspektywy rozwoju Indonezji jest brak poważniejszego zagrożenia zewnętrznego. Po okresie wstrząsów i napięć po odzyskaniu niepodległości i w czasach zimnej wojny, kiedy kraj przez lata żył w obawie przed interwencją zewnętrzną, dziś żadne państwo sąsiednie ani nawet mocarstwa obecne w regionie nie mogą lub nie mają interesu, aby zagrozić niezależności $\mathrm{i}$ integralności terytorialnej Indonezji. Pewne niejasności w relacjach z Chinami co do kontroli obszarów morskich w pobliżu wysp Natuna oraz drobne spory terytorialne z Malezją powodują napięcia, ale raczej nie grożą poważnym konfliktem. Nasilająca się rywalizacja chińsko-amerykańska i chińsko-japońska oczywiście znacznie komplikuje sytuację w regionie i wymaga umiejętnej i ostrożnej polityki Dżakarty, ale stwarza też nowe możliwości wygrywania tej rywalizacji m.in. w sprawach gospodarczych, czego przykładem był niedawny kontrakt na budowę szybkiej kolei na Jawie.

W interesie Dżakarty leży prowadzenie aktywnej i otwartej polityki zagranicznej, w dużym stopniu nastawionej na wspieranie rozwoju gospodarczego, w tym przyciąganie inwestycji zagranicznych, ale nie jest ona obciążona wymogiem przygotowywania się do stawienia czoła jakiemuś wyjątkowemu zewnętrznemu zagrożeniu. Kładąc akcent na gospodarkę, obecna polityka Dżakarty nie kieruje się też wymogami walki o pozycję regionalnego lidera. Bez wątpienia jednak los całego regionu będzie zależał w znacznym stopniu od przyszłości Indonezji.

Powyższe powoduje, że Indonezja nie musi szybko ani znacznie powiększać wydatków na obronę, choć od 2010 r. następuje ich stopniowy wzrost. Konieczne jest natomiast pewne dalsze zwiększenie nakładów, głównie na siły morskie w celu skutecznej ochrony zasobów morskich olbrzymiej strefy ekonomicznej, w dużym zakresie eksploatowanej przez obcych. W tym kontekście możliwy jest dalszy stopniowy i ograniczony wzrost budżetu obronnego, ocenianego w 2014 r. na nieco ponad 8 mld dol., czyli mniej niż 1\% PKB. 
Indonezja, bogata w zasoby naturalne i siłę roboczą, niewątpliwie ma niewykorzystane możliwości szybkiego wzrostu gospodarczego. Ważnym czynnikiem jest fakt, że 46\% indonezyjskiego PKB ma źródła w konsumpcji wewnętrznej. W kraju, w dużym stopniu jeszcze biednym, rozwój gospodarczy prowadzi do szybkiego wzrostu klasy konsumentów. W 2015 r. ich liczbę ocenia się w Indonezji na ok. $65 \mathrm{mln}$, ale źródła rządowe przewidują, że grupa ta wzrośnie do $135 \mathrm{mln}$ w $2030 \mathrm{r}$. i będzie potężnym motorem rozwoju. Wiele międzynarodowych agencji $i$ think thanków, m.in. McKinsey, przewiduje awans Indonezji w 2030 r. na siódme miejsce wśród gospodarek świata. Oczywiście gospodarka indonezyjska potrzebuje do tego znacznego napływu bezpośrednich inwestycji zagranicznych, a wraz z nimi nowych technologii i umiejętności w zakresie zarządzania, sprzyjających modernizacji i przyśpieszeniu rozwoju.

W tym celu konieczne jest, aby prezydent Jokowi z jednej strony realizował plan centralnych inwestycji $w$ infrastrukturę, $z$ drugiej kontynuował program wprowadzania nowych regulacji prorynkowych i skutecznie przyciągał zagranicznych inwestorów. Na razie, mimo postępu, Indonezja zajmuje dalekie 109. miejsce na 189 krajów sklasyfikowanych przez Bank Światowy, jeżeli chodzi o warunki prowadzenia biznesu. Drugą dziedziną, która będzie miała wielki wpływ na rozwój kraju, jest walka z korupcją i większa przejrzystość w sferze biznesu, szczególnie w sektorze publicznym. Tutaj Indonezja też ma wiele do zrobienia, bo wyprzedzają ją m.in. Chiny, Indie i cztery z państw ASEAN ${ }^{30}$.

Stawia to przed prezydentem niezwykle trudne zadania. Należy także mieć na uwadze wspomniane obawy i niechęć w społeczeństwie, ale i wśród administracji państwowej, do pozostawiania dużego marginesu swobody zagranicznym firmom. Obawy te są, zresztą nie bez powodu, mocno zakorzenione i niewątpliwie utrudniają racjonalne działanie w tej dziedzinie. Bez przesady można powiedzieć, że w związku z tym na prezydencie Jokowi ciąży wyjątkowy zakres i trudność zadań oraz wielka odpowiedzialność. Od jego stanowczości w reformowaniu, modernizowaniu i przebudowie gospodarki na bardziej otwartą i nastawioną na przetwórstwo oraz usługi, a więc z mniejszą rolą wydobycia i eksportu surowców, zależy przede wszystkim najbliższa, a być może i średniookresowa przyszłość Indonezji.

Wahania, a tym bardziej wycofywanie się z przebudowy gospodarki, a także istotne pogorszenie się sytuacji gospodarczej, niezależnie od przyczyn, może prowadzić do odżycia tendencji separatystycznych i ponownego ożywienia terroryzmu islamskiego. Skomplikują się wówczas także relacje z siłami zbrojnymi i uaktywnią się grupy nacisku związane z tradycyjnymi elitami indonezyjskimi. Pozycję prezydenta mogą zachwiać też takie zjawiska, jak wyjątkowy zasięg tzw. haze (chmury dymu), związanego z nielegalnym wypalaniem dżungli pod plantacje palmy ole-

${ }^{30}$ Filipiny, Malezja, Singapur i Tajlandia - „The Economist”, 6 czerwca 2015. 
jowej, który w 2015 r. doprowadził do śmierci i chorób wielu tysięcy Indonezyjczyków, niezależnie od wielkich strat w środowisku naturalnym.

Prezydent Joko Widodo jest niejako skazany na zdecydowany marsz ku realizacji swoich planów. Zbytnia ostrożność i wyczekiwanie na „sprzyjający moment” będzie prowadzić do marnowania szans, a w konsekwencji do skończenia prezydentury jak poprzednik, w atmosferze niedosytu i powszechnej krytyki. Natomiast sama Indonezja na wiele lat może pozostać krajem, który tylko „dobrze się zapowiada”. 